\title{
CONSUMERISM CAPITALIST PERSPECTIVE IN ANIMATION FILM SEN TO CHIHIRO NO KAMIKAUSHI BY HAYAO MIYAZAKI
}

\author{
Roberto Masami Prabowo \\ Japanese Department, Faculty of Humanities, Bina Nusantara University \\ Jln. Kemanggisan Ilir III No. 45, Palmerah, Jakarta 11480, Indonesia \\ rprabowo@binus.edu
}

\begin{abstract}
One of the works of Studio Ghibli who directed by Hayao Miyazaki entitled Sen to Chihiro no Kamikakushi (千と千尋の神隠し) would be discussed in this research about the capitalist consumerism. The research method in this research was qualitative and descriptive analytical method. The results of this research will provide the new insights into the animation appreciation and the understanding of the implicit context in the story. People can understand the politic, economic, culture of Japanese after watching the work of Studio Ghibli. The author hopes that the results of this article will produce useful conclusions and will be used for the next study.
\end{abstract}

Keywords: Japanese animation, capitalist consumerism, implicit message

\section{INTRODUCTION}

The animation is one of the literary works that is created into a form of an image, act, process, and conclusion of the live parts. Some animators work to shed the illustration of a person, but sometimes they try to reveal the message through these media, such as capture the physical, movement, and characters that have messages lies beneath. As expressed by Masami (2007), the Japanese call the animation or animeshon (アニメーション) with anime (アニメ). Anime is an uptake term by the Japanese people. Every summer, Japanese animation producers always make a long duration animation which is called animation film. This animation film is always anticipated by everyone in Japan or around the world. Sometimes, these animation films win the academic awards in Japan or are given by the American or Europe academic awards. The Japanese animation films are well known because the plot, characters, the unique technology, and the stories that are generally about the ecology and humanist (Itagoshi, 2014).

The main attractions of the anime are entertainment, fantasy, and imagination that cannot be happened in the real world. Norris (2009) has said that the anime is a contemporary Japanese visual culture and aesthetics in some media, cultural learning, and the media in responding the commentators around the world. For the Western culture, they say that animation is only for the children as an entertainment and it has not a specific meaning or value to be conveyed. Usually, anime can be considered as a means of entertainment and means to learn about Japan for people who watch it (Itagoshi, 2014).

An animator has a goal to deliver the vision and mission the story that illustrates the growing conditions in the surrounding communities. Isern and Donaghy (2012) have said that the animation plays a big role to understand the events that are really happening in the world. Japanese animation or 
anime can be enjoyed as entertainment that is examined more deeply. The story of anime illustrates the Japanese culture and people in daily life. If people can catch the whole story or the messages lie beneath, the anime could be not only the story that has a short conclusion with the happy ending. Some stories tell about the social problems and phenomenon that happened in Japan (Itagoshi, 2014).

Phillips and Stringer (2007) have stated that people can study the Japanese context with the anime because it is rich with the contemporary Japanese art with a special narrative and visual aesthetic that has relationships with the traditional Japanese culture. Anime has described the condition of society and culture in Japan that can be understood in detail as part of the learning community. In this research, it can be assumed that anime is one of the mass media that can look the condition of the society through the perspective of the vision and mission of its creator or animator.

One of the most popular anime or animation film in Japan is Sen to Chihiro no Kamikakushi (千と千尋の神隠し) or Spirited Away in English. This anime or animation film is produced by Studio Ghibli that released in 2001. The world has been discussing it until now, and it is considered as a successful animated film in Japan's history. Sen to Chihiro no Kamikakushi successfully receives a huge profit of around 30,4 billion yen, and it won several prestigious awards that were held in Japan and outside of Japan, including the Golden Bear in 2002 and the 75th Academy Award for Best Animated Feature in 2003.

Behind of the big success of this anime is Hayao Miyazaki, the director of this animation film. According to Lenburg (2012), Hayao Miyazaki is one of the most influential filmmakers who respected the animation. He also adds that Hayao Miyazaki is called as "the giant of anime" because he is always making the animation story with rich, pleasant, and extraordinary detail with interesting characters and stories. Through this animation, Miyazaki is pouring all his fantasies into the animation film. He almost takes all part in making an animation, such as story, pictures, screenwriter, and director. Miyazaki is inspired by many things around it, which the main character, Chihiro, is inspired by his daughter's friend. He drew the places such as restaurants, bathhouse, railway station, building, and much more and poured it into the anime to set the story. He is also inspired by his favorite restaurant that is building near Studio Ghibli. He will make everything as much he wants into the animation that makes it becomes fantasy and unique (Chambers, 2012).

There is a symbol that quite complex in the Japanese public life in Sen to Chihiro no Kamikakushi. Some cases or events that are occurred in the Japanese urban communities become a social critique as conveyed by Miyazaki. The situation and condition are also described as an implicit in some of the characters and scenes that contained in this animation. Each character like Chihiro or Sen, Chihiro parents, Haku, Yubaba, Rin, Kaonashi, and others, can be interpreted by the world society, particularly in Japan in the 1990s (Sukawa, 2014).

\section{METHODS}

This research uses qualitative research method and analytical descriptive. The data is collected by watching the animation, categorizes the scenes, analyzing, and connecting it with the other data. The object of research is analyzing the connection between the capitalist consumerism in Japan after the 1990s with the animation Sen to Chihiro no Kamikakushi. The researcher is collecting the data and materials related to the subject of this study by literary study. The data obtain through the sources of literature and scientific journals, such as books about the Japanese society and culture. This research aims to look for the symbols of capitalist consumerism which is represented in the animation Sen to Chihiro no Kamikakushi. 


\section{RESULTS AND DISCUSSIONS}

Sen to Chihiro no Kamikakushi is a story about ten years old girl named Chihiro who is being hidden by the god or spirited away by the god. Spirited away in Japanese is kamikushi which means a mysterious disappearance or death of a person that happens when the god angered or cursed that person. The reason why the god is hiding the human cannot be guessed by humans, and he does that for some reasons and the other purposes. In this anime, she is taken by the god because her parents do something wrong or not good in god's domain (Kawakatsu, 2014).

The story begins with a ten years old girl named Chihiro who is a whiny, pessimistic, and hate to live in the suburban. She thinks it will be better if she stays in town, rather than living in suburban. She also hates to make a new friend at new school, because she already has a best friend in town. While driving to the new house, Chihiro's father gets a wrong path, and he takes a shortcut that he assumes it could be the faster way to get to the new house. After they go through to the end of the road, they stop in front of the strange statue. Behind this strange statue, there is a mysterious big tunnel which leads to what appears to be an abandoned theme park. Suddenly, they catch a fine smell of food and Chihiro's parents are finding a restaurant that fully-stocked with the unattended owner, both parents decide to eat the food with voraciously and then turn into a pig (Sukawa, 2014).

When Chihiro's parents turn into a pig, Chihiro is shocked and runs to the path where they are coming, but she cannot that path because it is already full of water. She still believes that she lives in a dream and she is begging to herself to wake up. Suddenly, on the riverside, there is a ship arrived, and many gods have passed to that world. She frightens and runs to nowhere, feels down, and her body starts disappearing. She meets a mysterious boy named Haku who helps Chihiro and insists on taking a pill if she wants to live in this world. Haku advises Chihiro if she wants to live, she must work and eat the food in this world. So, he smuggles her into a large bathhouse which owned by Yubaba. The bathhouse is where thousands of gods or spirits come to bath and refreshing their bodies. Haku tells Chihiro that there is one way to rescue her parents that she must work for Yubaba for long enough, then maybe Yubaba can spare her parents.

This anime was creating the background during the Japan's post-destruction economic bubble that took an effect as a major change in Japanese society. There are so many conditions in Japan that are undergoing some dramatic changes after the collapse of the economic bubble. Especially, the economic collapses which drifting the new culture and psychology of Japanese society.

The researcher sees many conditions or social problems that can be re-thinking or analyze through the animation film Sen to Chihiro no Kamikakushi. However, the researcher sees the greed scene likely on the nature of human that brings to consumerism. Consumerism has many forms and categories. With this background, the researcher wants to analyze the consumerisms perspective by those figures which described by Miyazaki through Sen to Chihiro no Kamikakushi or known as Spirited Away.

On the first scene, Chihiro's parents go to their new home with Audi car that is driven by his father. Chihiro sits in the back of the car while continuing to embrace a bouquet of flowers that she receives from her friend in her old school because she moves to her new home and a new school. Phillips and Stringer (2007) have stated that the Audi car is being driven by his father Chihiro is a car from one of the countries in Europe, Germany. The emblem of Audi is known with four interrelated circles. It can be seen in Figure 1. 


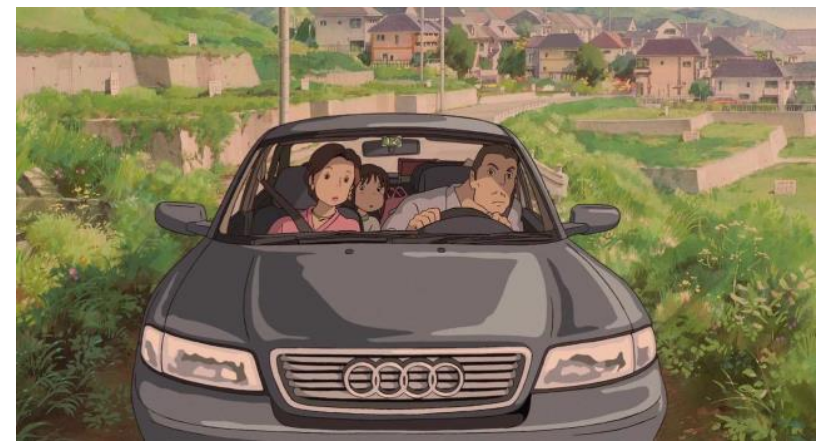

Figure 1 AUDI A4 Car

(Miyazaki \& Isao, 2002. 00:01:57)

Based on the documentary in bonus DVD that contains "Making of Sen to Chihiro no Kamikakushi", the car that is used by Chihiro's father is Audi A4. The narrator of this documentation film says that in making this film better for the sound of the car, they record the sound of AUDI A4's engine, the same car that is driven by Chihiro's parents. The purpose of this scene is for the audience to hear and feel vibrant of the 3000cc engine of the German model.

This animation represents a luxury car from German that they drive to the house. They are not using the ordinary family car, but the car with the highest technology on that year and the expensive one. In the hierarchy of the economy, the car is the luxury need. People can survive without a car, but for the urban life, there are other transportations than a car. So that, it can be regarded as a barometer of the economy and lifestyle. The car is not categorized as physiological needs in the hierarchy of needs or human motivation propounded by Abraham Maslow. The car is categorized as the tertiary needs, which is a requirement that can be fulfilled after the basic human needs comply. When it is viewed from the hierarchy of needs or human motivation of Abraham Maslow, the car is the security needs. The cost production of the imported car is expensive because it is exclusive; hopefully, it is better than the domestic car with sophisticated technology. It can be seen as a form of the search status (Lamerichs, 2013).

As stated by Suyanto (2013), the post-modernism is an era of complexity between desire and needs, and it is difficult to distinguish from others. It means that this is the era where the human ambiguity between their needs and desire. Some people purchase a goods and services not just for the value that they emergence for the lifestyle and that needs cannot be postponed for next time. The researcher notices that the parents who buy an import car are the one who searches the status and lifestyle. Because the car has the value of benefits as the means of transportation and that product that is used by Chihiro's parents is from German that its price is more expensive than the domestic car.

The conditions of Japanese society are also described by Haghirian (2010) at the period of the bubble economy of the 1980s. There is a shift from the beginning of the Japanese-oriented conformists; then it can be oriented on the search status. Hence, the needs for a car of that era is measured by the theory needs or human motivation that is described by Abraham Maslow. It is the motivation of the security needs that may be considered as a need for prestige that he/she has the status of noble birth in communities. The purpose of Chihiro's father buys this luxury car is because his family will be considered a settled family from others that makes them more comfortable.

Suyanto (2013) has stated the lifestyle and prestige in urban communities that consume everything has a high value, practical, sophisticated, and search status. The society is constantly in search of such status that can be said or categorized as a society capitalist consumerism. On the socioeconomic structure of society, the needs of society are distinguished from the needs of classes, 
strata, social groups, and individuals. Depending on the role played by their satisfaction in the reproduction of human capabilities, the economic needs are classified as social, physical, and intellectual.

In minutes 0:08:30 to 00:09:40, Miyazaki pictures the father and mother are taking a meal at some restaurant which there is no owner. They eat as much as they can and do not feel guilty if they cannot pay. This scene starts when Chihiro's father sees some steam and smells the delicious foods, then they rush over to that restaurant. Chihiro's mother is also tempted because of the scent of the tantalizing dishes and overflows. She decides to eat after his husband; then she says not to worry because father will pay with cash or credit card. Chihiro does not want to eat because she is afraid of being scolded by the owner. Then she insists going back home, but her parents do not notice and continue to voracious eat without talking.

In an economic crisis, many people assume that there will be a shortage of food maybe that is the reason why they do not want to starve. After they eat too much, they will feel safer. In another side, if they do not have much food or money to buy some, other people will assume this man or woman do not have any potential to live in town. To live in town, it depends on how much money we have, not how to keep the money or food. Sometimes skill is not necessary to keep in life, but how to have the money are the keys to live in town (Lamerichs, 2013). Figure 2 shows the scene where the Chihiro's parents become the pig after eating too much food.

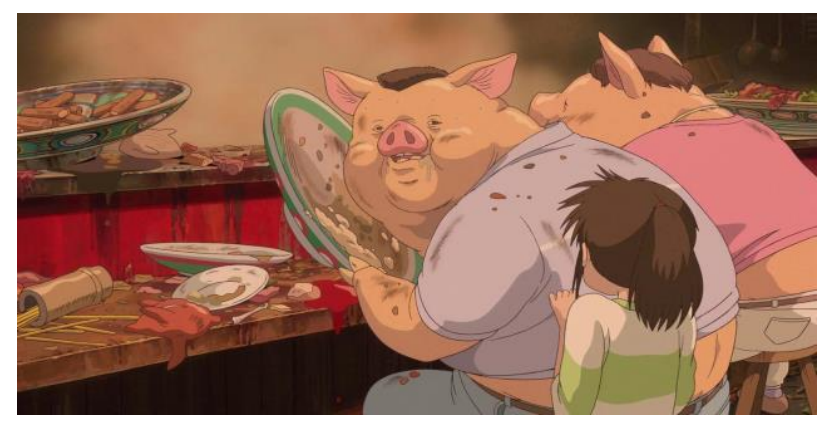

Figure 2 Scene of Chihiro's Parents Turn into a Pig (Miyazaki \& Isao, 2002. 00:12:10).

Because both Chihiro's parents consume the food so voraciously, they turn into a pig. Usually, people see the others who eat voracious or greedy as a pig because of their behavior. But in this animation film, Hayao Miyazaki depicts Chihiro's parents become a pig because the pig will be used for the raw material for the next meal. The researcher interprets this scene with the theory from Michael Hill (2008). The pig is pictured to be the next meal has the same meaning as the picture chain consumerism capitalist. If he/she consumes a product with the capitalist system which is buying something with money or credit card, so he/she already has entered the cycle of the chain of capitalist consumerism. It is disclosed in the animation of Chihiro. If someone eats too much then gets fat; he/she will be eaten by other things. The message of it is people who consume excessively and continuously will become consumerism (Hawkins, Mothersbaugh, and Best, 2012).

The next scene that is described in this article is the scene in Yubaba's luxury. The human needs have three levels; it is primary, secondary, and tertiary. The primary needs are natural or unlearned needs or requirements that are determined by the factors innate to a person or his or her environment, such as for food, security, and shelter. Then the secondary needs include recreation and entertainment. The last one is tertiary needs; it is measurable manifestations of the requirements or motives. Usually, these needs are collected after primary and tertiary had already accomplished. At the 
minute 00:35:10, the hall where Yubaba's lived looks very luxury. There are antique urns, large wooden doors, chandeliers, wall, and the mirror frame that show Renaissance era style. The looks of her room or corridor are usually owned by the rich people or the museum house in Europe. It can be seen in Figure 3.

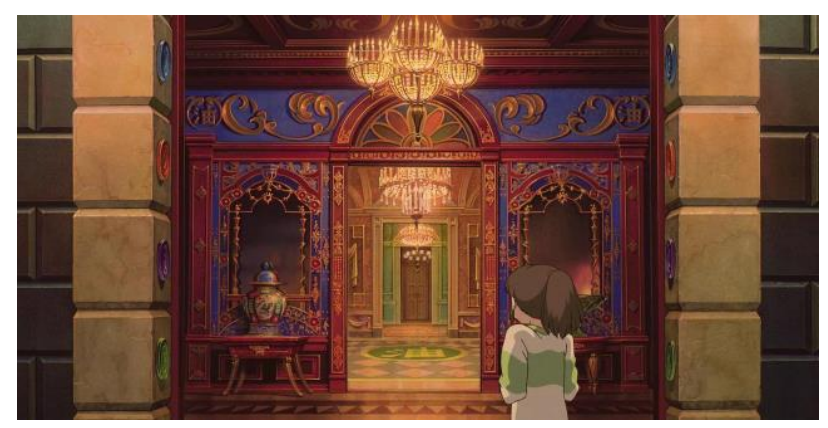

Figure 3 Chihiro Tries to Enter Yubaba's Workplace (Miyazaki \& Isao, 2002. 00:35:12).

Yubaba is the owner of the bathhouse. She wears the diamond ring on each finger and petticoat clothes that are the model from around 1950s fashion. Moreover, she seems preoccupied with her job; contract signing and counting money. The depiction of Yubaba can be seen in Figure 4.

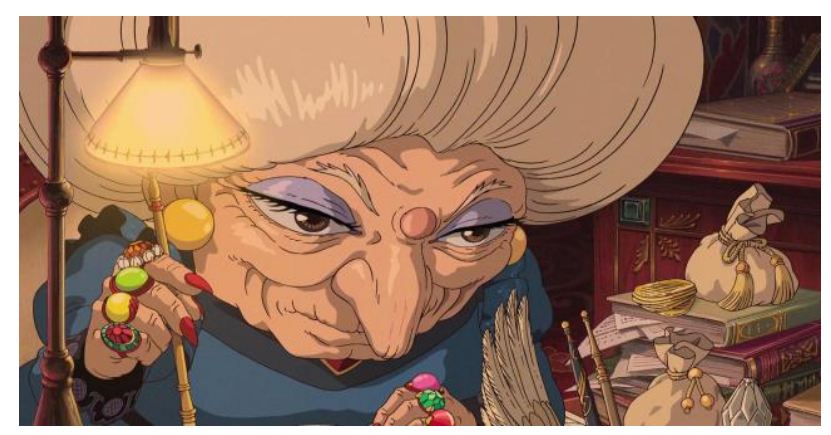

Figure 4 The Depiction of Yubaba's Luxury

(Miyazaki \& Isao, 2002. 00:36:05)

In 0:54:30, Yubaba are busy assessing the quality of the gemstones or diamonds for a gift or tribute to the guests. As a means of transactions that previously have been discussed, money and credit card, jewels or other precious things that might have a high potential selling power and could be used as pay method. In addition, those gemstones or diamonds can be used by her as an accessory to enhance the beauty, confidence, and luxurious. It can be seen in Figure 5. 


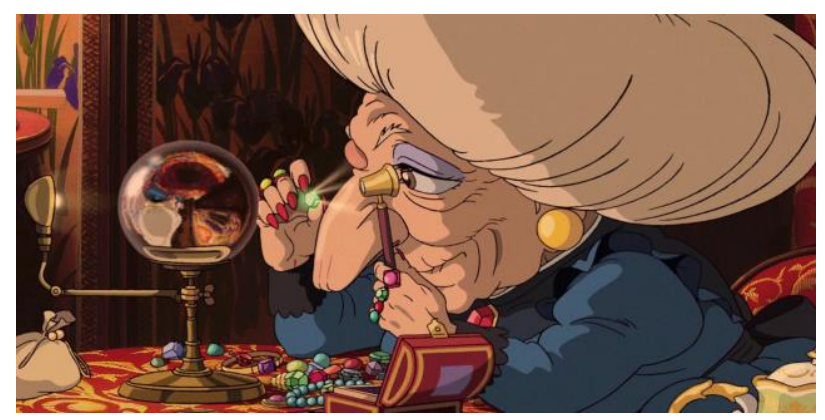

Figure 5 Yubaba Observes the Quality of Gemstone (Miyazaki \& Isao, 2002. 00:54:30).

The terms of need from Abraham Maslow's theory, the jewelry has been entered the third category, tertiary needs or esteem needs. Jewelry is not the basic needs to makes a human being to survive, but it is a need for prestige. By having jewelry, one will highly regard and get status from others. As stated by Campbell in Suyanto (2013), in the society, the consumer will tend to reach the high levels of consumption for personal happiness as high society does, so they just manipulate that act as the goal of his/her life. Thus, the researcher also concludes that if Yubaba has more jewelry, she will be on the higher social level than others who do not have. That act is the same as a consumerism in the present day. The indications of that sign are described by Hayao Miyazaki through Yubaba, such as having an expensive jewelry is a form of consumerism. The expensive jewelry is not a human need; they can survive physically without jewelry. But the jewelry is a necessity to get a higher status in the society. Through this animated scene, Yubaba indirectly has needed to get recognition from the others, such as status, fame, domination, pride, adore, and others (Yamanaka, 2008).

Yubaba's name in Japanese letters is written as 湯婆婆. It is taken and changed a little from the name of Yuya (湯屋) which means bathhouse. Yuya is not a regular bathhouse. This bathhouse is only for men. In this anime, Yuya is not written as 湯屋, because it is too vulgar for the children. So that the name is changed and written with 油屋 which means oil house. As Haku said, if Chihiro wants to live, she must work and eat from this world, so Chihiro has no choice to work in this bathhouse. In the past, the service girl who worked in Yuya named Yuna (湯女). Yuna can be read as Yujo that can be called as prostitution in the red-light district. Those girls who work as Yujo will entertain the customer for a few minute for a high price, and the ordinary people cannot easily get access to this prostitution (Yamanaka, 2008).

Kaonashi is kind of a spirit in Yubaba's world. It will stalk someone if he/she shows the sympathy, bizarre, and pathetic to this creature that has no identity. It can speak as the same voices as the person that it swallowed. The first time, it meets with Chihiro that appears like a semi-transparent while shifting in and out of visibility. His figure resembles a long, black tube, and wearing a mask. Kaonashi means no-face that means abandoned god. Miyazaki also interprets the character with black color, gradient texture, changeable shape, dark appearances, etc. (Yamamura, 2008). Figure 6 shows the depiction of Kaonashi. 


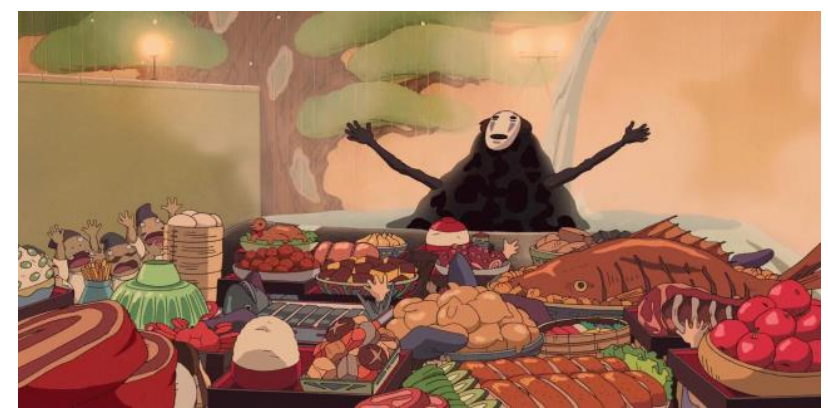

Figure 6 Kaonashi Buys Food with Throwing Gold and Eats Voraciously (Miyazaki \& Isao, 2002. 01:11:24)

Iles (2008) that cites Shimizu tells that Kaonashi not only have no face, but it also cannot even speak; it is just a lonely soul that craves what it wants. Shimizu in Iles (2008), Kaonashi is described as a symbol of contemporary young people which do not have a face and have lost the face of their character. Shimizu continues that the black-clad figure symbolizes not faced him in the traditional meaning of mu or 無 which means "nothing" in a Buddhist Zen. Nothing which means is kyomu (虚無) or emptiness, hollow, boundless greed which no end that is fill in the blanks of existence without end.

Yamamura (2008) has interpreted that Kaonashi figures may be the interpretation of Japan's lonely young people who do not know how to make a friend. In this animation film, Kaonashi is a lonely spirit who has a lot of money and he thinks with that money can buy everything. This act is the same as young people in Japan, they have a lot of money but have no friends. With the power of money, they think it can buy everything. In this anime, Kaonashi can eat anything, but Kaonashi eats those things mean anyone could eat anything and that thing could be alive as a spirit. Figure 7 shows that Kaonashi uses his money to make Chihiro serve him.

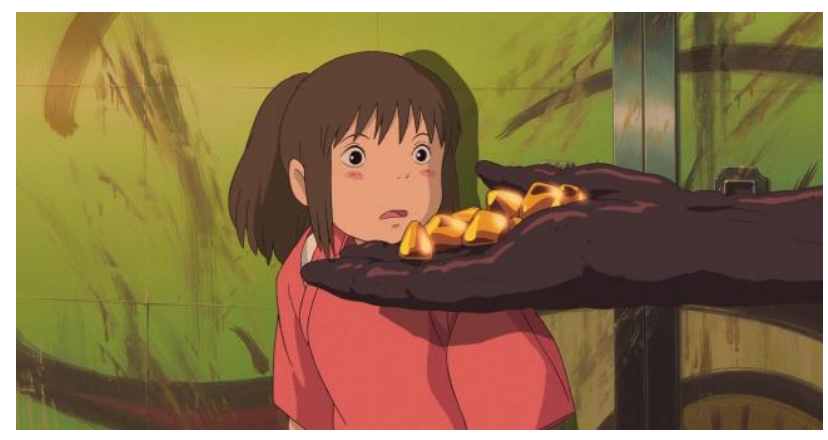

Figure 7 Kaonashi Buys or Bribes Chihiro with Gold (Miyazaki \& Isao, 2002. 01:33:53)

From the Kaonashi character, the researcher could see Miyazaki gives a sharp social critique of consumerism prostitution of young children in modern Japan era. The researcher also captures the implicit meaning of this as the form of someone who suddenly has everything turns into the uncontrolled monster (Solomon, 2015). Kaonashi act can be categorized into the level of self-esteem. It wants to be appreciated by those who have a lot of money and respected by the others. If someone rejected it, it would eat them until getting satisfied. That is like the capitalist society in Japan, with money, people can buy everything until they satisfy or broke (Chambers, 2012). 
From these scenes that have been discussed, there are many symbols and icons that depict the consumerism and capitalism in the post-bubble economy in Japan. In theory of needs according to Maslow (2013), he also mentions that human needs consist of physiological needs or basic needs, needs for security (safety), needs to be loved and cherished (love/belonging), needs to be valued (esteem), and the needs for self-actualization (self-actualization). It can be seen in Figure 8.

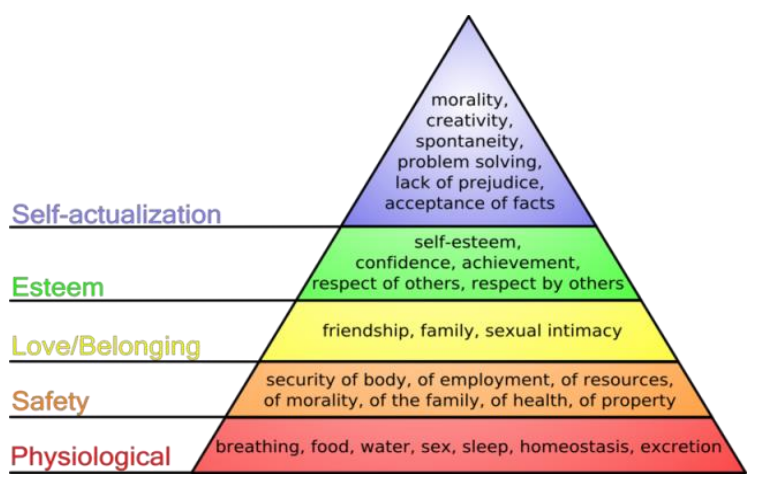

Figure 8 Hierarchy of Needs by Abraham Maslow

Maslow in Griffin and Moorhead (2016) has developed the theory of human motivation and variation of human needs that can be arrayed in the form of a hierarchy. Each level of needs has a level from bottom to upper, but each level must full field until getting satisfied. The study of motivation for goods or objects is connecting. If someone has a motivation to increase their needs, they need to increase it from lower level to upper level, but they must fulfill each step. Kawase and Nakamura (2007) have also noted from the five requirements, self-actualization is higher than the selfesteem. The second needs are for the recognition from others, status, fame, domination, pride, considered important, and appreciation of others. Self-actualization is the highest level of needs which is focused on the reality (reality-centered), have a sense of complacency high recognition from the others, and acceptance of ourselves as individuals.

The top of needs is the needs for strength, mastery, competence, confidence, and independence. Secondly, there are needs for recognition from others, status, fame, domination, pride, considered important, and appreciation of others. The fourth needs are living in warm, safety, and sanitize the area. The lower needs or a basic need is the needs which cannot be postponed because it will affect the human health.

\section{CONCLUSIONS}

The animation film Sen to Chihiro no Kamikakushi or Spirited Away by Hayao Miyazaki has a lot of symbols and icons. Because of that, it creates new insights for the people to see the world of capitalist consumerism and social criticize of the establishment in the social status. The anxiety of Japanese economy devastation also triggers the uncontrolled consumerism, because it concerns the limitations the price for the expensive goods.

Several urban people generally prefer to purchase the goods or consume something that convenience, practical, and inexpensive. Upon the entry of civilization means of payment with cash, people tend to be lazy in looking for cook or farming. Moreover, in the present day, the credit card is the most potential tool for the transaction or buys things without thinking, and that easiness can switch 
the needs into the wants. In addition, discounts and promotions from the credit card are the triggers of opportunity for the people to purchase the products. Finally, the goods which have consumed will be as the value of the sign (sign value) and not the value of the benefit (benefit value).

The criticism of prostitution for the young children in Japan is also discussed in this animation film. There are some groups in Japan who exploited the children into prostitution with the promises to establish their lives. Usually, these girls also get paid after they have done the services and get paid from the sponsors as well as from the syndicate. These payments also can be used for their primary, secondary, and tertiary needs. Some girls who get comfortable in this domain, they will live without thinking about their future. For the girls who are entangled in this syndicate, it will be hard for them to get out from this sex trade network.

The capitalist consumerism phenomenon is rooted in the ease of the payment, such as credit card, ATM, online banking, mobile banking, etc. Eventually, Maslow's theory of hierarchy needs depends on the motivation. Thus, for the market traders, they do not need to fear to sell their products if this system does not defect or has a limitation.

\section{REFERENCES}

Chambers, S. N. I. (2012). Anime: From Cult Following to Pop Culture Phenomenon. The Elon Journal of Undergraduate Research in Communications, 3(2), 1-3.

Griffin, R. W., \& Moorhead, G. (2011). Organizational Behavior: Managing People and Organizations. Boston: South-Western College.

Haghirian, P. (2011). The Historical Development of Japanese Consumerism. London: Palgrave Macmillan.

Hawkins, D. I., Mothersbaugh, D. L., \& Best, R. J. (2013). Consumer Behavior: Building Marketing Strategy. New York: McGraw - Hill International.

Hill, M. (2008). Japanese HSC Extension Course Support Materials 2009-2013: Material Set 1 Anime Background Notes. New South Wales: NSW Department of Education and Training, and Association of Independent Schools of New South Wales.

Iles, T. (2008). The Crisis of Identity in Contemporary Japanese Film: Personal, Cultural, National. Leiden: Brill.

Isern, M. T. I., \& Donaghy, K. (2012). Films in Health Sciences Education: Learning Through Moving Images. Barcelona: Edicions Universitat Barcelona.

Itagoshi, T. T. (2014). Rebuilding of the Competitive Strategy for Japanese Companies in the U.S. Anime Market. 情報社会学会誌, 9(1), 43-53.

Kawakatsu, M. (2014). The Downfall of Gods in "Spirited Away" A Mirror Image, the Overturned Scenery and “Reversible Destiny-Yoro Park” (『千と千尋の神隠し』における神々の零 落). Saitama Gakuen Daigakukiyō. Ningen Gakubu-Hen (埼玉学園大学紀要. 人間学部篇). 13, 181-192. Retrieved from http://www.media.saigaku.ac.jp/bulletin/pdf/vol13/human/15_kawakatsu.pdf. 
Kawase, Y., \& Nakamura, K. (2007). 人閒形成の教育一教育相談と発達援助の教育に関わって (Education of human formation - concerning education consultation and education of development aid). Tokyo: 相川書房 (Aikawa Shobo).

Lamerichs, N. (2013). The Cultural Dynamic of Doujinshi and Cosplay: Local Anime Fandom in Japan, USA, and Europe. 10(1), 154-176. Retrieved from www.participations.org/Volume\%2010/Issue\%201/10\%20Lamerichs\%2010.1.pdf.

Lenburg, J. (2012). Legends of Animation: Hayao Miyazaki. New York: Chelsea House.

Masami, S. (2007). 日本アニメの現在と将来一人的資源の視点からの考察一(Present and Future of Japanese Animation - Consideration from the Viewpoint of Human Resources -). Nagoya University of Commerce \& Business Administration. NUCB Journal of Economics and Information Science, 52(1), 23-33. Retrieved from http://ci.nii.ac.jp/els/contentscinii_20170615132804.pdf?id=ART0008393712.

Maslow, A. H. (2013). A Theory of Human Motivation. USA: Martino Fine Books.

Miyazaki, H., \& Isao, T. (2001). Spirited Away/Sen to Chihiro no Kamikakushi. Japan: DVD Studio Ghibli/Disney Studios.

Norris, C. J. (2009). Manga, Anime and Visual Art Culture. The Cambridge Companion to Modern Japanese Culture. Australia: Cambridge University Press.

Phillips, A., \& Stringer, J. (2007). Japanese Cinema: Texts and Contexts. New York: Routledge.

Solomon, M. R. (2014). Consumer Behavior: Buying, Having and Being. Boston, Mass: Pearson, Prentice Hall.

Sukawa, A. (2014). アニメ・マンガにみる家族表象とジェンダー問題. 東京 : 青山学院大学国 際交流共同研究センター (Tokyo: Aoyama University Joint Research Institute for International Peace and Culture). Peace and culture Journal, 6(1), 57-74.

Suyanto, B. (2013). Sosiologi Ekonomi: Kapitalisme dan Konsumsi di Era Masyarakat Post Moderenisme. Jakarta: Kencana Prenada Media Group.

Yamamura, T. (2008). アニメ聖地の成立とその展開に関する研究 : アニメ作品「らきうすた」 による埼玉県熟宮町の旅客誘致に関する一考察 (Study of Birth and Development of "Sacred Place for Anime Fans": Discussion of Tourist Promotions Based on Animated Work “Luckey Star” Focused on Washimiya, Saitama Prefecture). 国際広報メディア・観光学ジ ヤーナル (The Journal of International Media, Communication, and Tourism Studies), 7, 145-164. Retrieved from http://hdl.handle.net/2115/35084.

Yamanaka, H (2008). The Utopian "Power to Live"; The significance of the Miyazaki Phenomenon. In MacWilliams, Mark W. (Eds); Schodt, Frederik L. (Foreword by), Japanese Visual Culture: Explorations in the World of Manga and Anime. Armonk, NY, USA: Routledge. 